\title{
Trans Pacific Partnership and China's Involvement: How Can Indonesia Benefit from Both Worlds?
}

\author{
Ahmad Syaifuddin Zuhri \\ Dept. of International Relations \\ UIN Syarif Hidayatullah, Jakarta, Indonesia \\ zuhri_as@yahoo.co.id \\ Fadlan Muzakki \\ School of Public Affairs \\ Zhejiang University, Hangzhou, China \\ fadlanmuzakki@zju.edu.cn
}

\begin{abstract}
The involvement of China in TransPacific Partnership Agreement has brought a new chapter for this agreement. China seems to overtake the US Position after the country dropped from the partnership. Indonesia's has a considerably important position in both this partnership and relationship with China. It is because Indonesia lies in the strategic geographical area in Asia Pacific and also for 21century Maritime Silk Road Initiative. Therefore, this work is aim to questioning how Indonesia can take advantages from both Trans-Pacific Partnership and the Relationship with China. This paper seeks to unearth the potential of Indonesia to take benefits from Trans-Pacific Partnership and the involvement of China in the framework. This paper examines three sectors: economic, politics, and socio-cultural field to get more comprehensive views on the benefits that Indonesia can grab. Moreover, this study also considers challenges which may appear from taking both benefits from China and Trans-Pacific Partnership. The domestic condition in Indonesia and the perception of Indonesian society are also considered in examining those advantages.
\end{abstract}

Keywords: Indonesia, China, Benefits, Politics, Economy, Social, Cultures

\section{INTRODUCTION}

Trans-Pacific Partnership has grabbed the world attention as this framework invites opposition from some countries while some other are joining this partnership. The Trans-Pacific Partnership (TPP) set the rules for global trade which will help to increase the exports of the American-made products, enhance the growth of American economy, support well-paying American jobs and strengthen the American middle class. The TPP began as an expansion of the Trans-Pacific Strategic Economic Partnership Agreement (TPSEP or P4) signed by Brunei Darussalam, Chile, New Zealand, and Singapore in 2005. In 2008, additional countries joined the discussion for a broader agreement; those are Australia, Canada, Japan, Malaysia, Mexico, Peru, the United States, and Vietnam. Hence, twelve countries are participating in the negotiations. Current trade agreements between participating countries, such as the North American Free Trade Agreement, will be reduced to those provisions that do not conflict with the TPP or provide greater trade liberalization than the TPP. The Obama administration considered the TPP a companion agreement to the proposed Transatlantic Trade and Investment Partnership (TTIP), a broadly similar agreement between the U.S. and the European Union.

TPP is likely to bring China's neighbors closer to the United States and reduce their dependence on Chinese trade. If ratified, TPP strengthens American influence on future rules for the global economy.

China appears to currently have enough international economic negotiations on the table to keep it occupied, and it is unlikely that it is really concerned about the TPP. The nation is a sufficiently large player in the world economy to negotiate successfully with trading partners. China is already in the process of participating in the Silk Road project, the Asian Infrastructure Investment Bank, the New Development Bank, and other highlevel economic structures. If the TPP is proven to be valuable, perhaps China will join the alliance in the coming months. Hence, it may be beneficial if the treaty is not positioned as an anti-China agreement going forward

Indonesia's response to joining the partnership has been lukewarm and apprehensive. Indonesian Trade Minister Gita Wirjawan has hinted that Indonesia may join the negotiations after considerable progress was made on both Indonesia's trade agreement with South Korea and the Regional Comprehensive Economic Partnership (RCEP). RCEP is a regional trade agreement 
between the Association of Southeast Asian Nations with Australia, China, India, Japan, South Korea and New Zealand. Though it is more or less indisputable that the economic benefits in purely monetary terms from the RCEP would be higher than those from the TPP, the challenges and roadblocks in case of the RCEP are higher, too. The reason that monetary benefits would be higher in the short to medium term in the case of the RCEP is that the existing trade barriers are very high among the majority of the RCEP nations and lifting those barriers would result in immediate gains, while the TPP member countries are already relatively adopting open economies. The issue here is that Indonesia needs to view the RCEP and the TPP as two different agreements, each with their own set of benefits and peculiarities. The existing conditionality that the TPP would be pursued only if the RCEP goes through is based on the flimsy belief that the RCEP is relatively easier to conclude.

\section{RESEARCH QUESTION}

How can Indonesia take economic, political, and socio-cultural advantageous from both TransPacific Partnership and the Relations with China?

\section{RESULT AND DISCUSSION}

The TPP, spearheaded by the USA, is designed to enhance trade among the 12 members (USA, Japan, Malaysia, Vietnam, Brunei, Chile, New Zealand, Singapore, Australia, Canada, Mexico, and Peru) by lowering tariffs for a wide variety of products. Through the liberalization of trade (at least to a high degree), the TPP targets to boost economic growth, enhance job opportunity as well as innovation, productivity, and competitiveness. Also to reduce poverty, promote transparency and good governance, and improve both labor and environmental protection in the member countries. The TPP is one of the world's most ambitious trade deals covering an area that accounts for about 40 percent of total international trade.

Although Indonesian President Joko Widodo seems to support the participation in the TPP trade deal, plenty of resistance still exists. Those that oppose Indonesia's participation in the TPP say that the nation would merely become a consumer of foreign products. Given that Indonesia has a huge domestic market while Indonesian products lack competitiveness (compared to products imported from abroad). Hence, the deal will bring a massive inflow of the cheaper foreign goods with higher quality compared to the local products.
TPP members are spread across the Asia-Pacific region, which is geographically favorable for Indonesia. It has two of Indonesia's major trading partners - the United States and Japan - where the trade balance between the two countries has always been a surplus. TPP's reduction in 18,000 tariff and other non-tariff barriers opens up market access for member countries. This includes tariffs for textiles and apparel, one of Indonesia's main export products to the US. The agreement may also benefit members by providing regulations that guarantee a clearer and fairer trade practice.

The TPP is expected to help reduce poverty and improve human development through support to small producers. Aside from the potential benefits of higher market access by being a member of the TPP, Indonesia should also consider the cost of not joining this partnership. A 2013 study by the Asian Development Bank Institute shows that the nonmember countries including Indonesia can experience economic losses, by being less competitive from members in the same competing markets.

For example, not joining the partnership means Indonesia would be less competitive than the TPP members such as Malaysia and Vietnam, also to the large producers and exporters of textiles. Nevertheless, market access and tariff reductions are not the only areas that we have to consider in deciding to join. The TPP covers the so-called "21st-century issues" - such as intellectual property (IP) protection, investment assurance, movement of people, rules of origin, environmental protection, and labor standard. Experts in Indonesia must look into how the TPP will affect Indonesia's growing digital industry and e-commerce, as well as the movement of people between member countries.

Indonesia has a lot of homework to do. It is still facing the rapidly growing and modernized global market. Criticism certainly can guide us to act carefully, but we also need to be aware of the global opportunity and the risk of missing out when we are excluded from a strategic partnership. Indonesia should make its decision based on a comprehensive study of all aspects of the TPP to gain the full benefit of the agreement and be prepared for all its challenges. Additionally, to compete in a globalized economy, Indonesia must improve its infrastructure - especially roads and ports for transportation of goods and power plants to provide energy for manufacturing. Its institutions and human resources should also be improved. Any trade agreements have some degree of flexibility. We should not be stuck in the dichotomy of join or not to join. But we should find a middle ground of joining at a certain rate of conditions. 
Given that Indonesia has long refrained from committing to the Trans-Pacific Partnership (TPP), President Joko “Jokowi” Widodo's announcement in late October that "Indonesia intends to join the TPP” came as a surprise to many countries. Jokowi's statement directly followed his trip to Washington, D.C., where he had a meeting with Barack Obama to discuss the possibility of Indonesia joining the massive Pacific Rim trade agreement.

With his endorsement of TPP, Jokowi has signaled that he is getting serious about attracting more significant foreign investment to Indonesia's shores and moving the country away from its nationalist economic policies. Through TPP, Indonesia's small and medium-sized enterprises (SMEs) will have greater access to the markets from as geographically close as Australia to as far as Canada, allowing them to expand capacity and create more jobs at home. Also, TPP will put Indonesia in a single market with countries that make up a fourth of the global trade market. Tariffs on various items and industries such as agricultural products, financial services, tourism, insurance and capital transfers will be completely dissolved between the TPP members.

Domestically, there is an inherent skepticism among citizens on foreign investment and policies that are perceived as neoliberal - this skepticism is exacerbated by well-entrenched interest groups and local political candidates that try to prove their national loyalty. But part of Jokowi's election mandate was to break away from the cronyism and dynastic politics that mar Indonesia's past. Joining TPP will help him to do so by allowing the 12 other TPP members to bid on Indonesian infrastructure contracts - a departure from the usual priority given to state-owned enterprises with ties to powerful political families and bureaucrats.

The sheer size and policy reach of this agreement should be seen as an incentive for ratification in both the Indonesian legislature and the legislative bodies of existing TPP countries. The pact that was initially hailed in the West as a check on China's power in Asia, should be viewed as an opportunity to set a precedent on trade standards throughout all of Asia, ahead of the finalization of the Free Trade Area of the AsiaPacific (FTAAP).

Being part of the global trade game is important for Indonesia. The government has admitted that the country requires nearly $\$ 400$ billion over the next five years in order to meet infrastructure needs. Participating in a single market with the 12 TPP nations could help to close this gap. Indonesia is already a member of other multilateral initiatives like the World Trade Organization's Information Technology Agreement and the proposed Regional Comprehensive Economic Partnership (RCEP). Joining TPP would only enhance its access to global markets.

There are several things that Jokowi can do within the next two years to deliver on his October statement. First, he should sell the benefits of TPP to Indonesia's SMEs, as TPP participation would provide them with a single set of trade rules and regulations when dealing with multiple countries, as opposed to multiple rules when dealing with a couple of countries. Besides, many SMEs do not have the legal resources enjoyed by their larger multinational counterparts to keep up with the current model of tariffs and barriers. Second, to expedite ratification, Jokowi should build promultilateral trade partnerships in the legislature with members of the opposition majority party and among the smaller parties inside his coalition.

Third, and more immediately, Jokowi should stand firm in his commitment to relax existing hiring quotas and mandatory language requirements for expatriates, often cited by foreign firms as a reason why doing business in Indonesia is a headache. This would smooth the transition to the "high standards" required by TPP, harmonizing Indonesia's rules with those of existing members. It is not as it would be no global interest in Indonesia. U.S. giants like Apple and Google are stumbling over each other to gain direct access to Indonesian tin, an essential component of the iPhone and other products. Additionally, Jokowi closed billions of dollars' worth of oil and gas deals before leaving Washington, including investment commitments from U.S. stalwarts General Electric and Caterpillar.

For his part, Jokowi has begun to show that he takes his relations with the West seriously - and this is a positive development, regardless of whether it stems from political reasons or economic necessity. In November, after signing businessboosting contracts with President Sergio Mattarella, Jokowi appointed a special minister to work specifically on Indonesia's relations with Italy. At the same month, he reset Indonesia's relations with Australia by hosting new Prime Minister Malcolm Turnbull following the fallout of the death of an Australian citizen by firing squad for drug-related offenses. Indonesia's window of opportunity to become a leader among its regional neighbors and a stronger global power will not stay open for long. By joining TPP, the nation would take a giant step forward in becoming both. Otherwise, it risks being left miles behind. 


\section{Reference}

[1] Bernard K. Gordon, "Trading Up in Asia: Why the United States Needs the Trans-Pacific Partnership”, Foreign Affairs,Vol. 91, No. 4 (JULY/AUGUST 2012), pp. 17-22. Availablle at JSTOR : http://www.jstor.org/stable/23218036

[2] James Rude and Henry An, "Trans-Pacific Partnership: Implications for the Canadian Industrial Dairy Sector”, Canadian Public Policy / Analyse de Politiques, Vol. 39, No. 3 (September 2013), pp. 393-410. Availablle at JSTOR http://www.jstor.org/stable/23594718

[3] Arthur Stamoulis, "Trading Away the Future: An Analysis of the Trans-Pacific Partnership", Source: New Labor Forum,Vol. 22, No. 3 (Fall 2013), pp. 30-37. Available at http://www.jstor.org/stable/24718485

[4] Patrick Messerlin, "The EU's Strategy for TransPacific Partnership", Journal of Economic Integration,Vol. 28, No. 2 (June 2013), pp. 285302. Available

at http://www.jstor.org/stable/41959034

[5] The Trans Pacific Partnership Website, What is the TPP, accessed in $1^{\text {th }}$ September 2017, Available at https://ustr.gov/TPP/\#what-is-tpp

[6] Isfeld, Gordon (12 October 2015). "Forget NAFTA, the TPP is the new 'gold standard' of global trade". Financial Post. Toronto: National Post.

[7] Russel, Daniel. "Transatlantic Interests In Asia". U.S Department of State.

[8] svwriter, John Boudreau. "The Biggest Winner From TPP Trade Deal May Be Vietnam". Accessed in 29 August 2017 Available at Bloomberg.com.
[9] Foreign Policy, "What Will the TPP Mean for China?". Accessed in 10 August 2017, Available from Foreign Policy.

[10] Routers Magazine, "Killing TPP would hand China 'keys to the castle': U.S. trade representative". Reuters.

[11] The Diplomat, China and the Trans-Pacific Partnership, Accessed in 20 August 2017, Available at http://thediplomat.com/2015/10/china-and-thetrans-pacific-partnership/

[12] Jakarta Globe, Indonesia and the Trans Pacific Partnership to Join or Not, Accessed in 15 August 2017, Available at http://jakartaglobe.id/opinion/indonesia-and-thetrans-pacific-partnership-to-join-or-not-to-join/

[13] Electronic Frontier Foundation, What Was the Trans-Pacific Partnership Agreement?, accesed $1^{\text {st }} \quad$ September 2017, Available at https://www.eff.org/issues/tpp

[14] Indonesia Investment, “CSIS: Indonesia benefits when Joining the Trans Pacific Partnership https://www.indonesia-

investments.com/news/news-columns/csisindonesia-benefits-when-joining-the-transpacific-partnership/item6649

[15] The Conversation, Wighing the Cost and Benefits of Joining Trans Pacific Partnership for Indonesia, Accesed in 13 August 2017, Available at http://theconversation.com/weighing-the-costsand-benefits-of-joining-tpp-for-indonesia-54376

[16] The Diplomat, "Why Indonesia Joining the Trans Pacific Partnership would be a Good Thing, Accesed in 22 August 2017, Available at http://thediplomat.com/2015/12/why-indonesiajoining-the-tpp-would-be-a-good-thing/ 